Journal of Mathematics and Statistics 5 (4): 287-297, 2009

ISSN 1549-3644

(C) 2009 Science Publications

\title{
Assessing Computer Knowledge in Senior High School: A Case Study of the Upper East Region in Ghana
}

\author{
${ }^{1}$ Oladejo, N.K. and ${ }^{2}$ I.A. Adetunde \\ ${ }^{1}$ Department of Applied Mathematics and Computer Science, \\ University for Development Studies, Navrongo, Ghana \\ ${ }^{2}$ Department of Mathematics, University of Mine andTechnology \\ Tarkwa, Ghana
}

\begin{abstract}
Problem statement: This study contracted with assessing the knowledge of computer in Senior High Schools of the Upper East Region in Ghana. Approach: Data collected by means of administration of questionnaire brings out the level of computer knowledge expected from a student completing a Senior High School in the Upper East Region in Ghana. 140 sample students from 8 districts were selected for the study. Results: Hypotheses were tested at $\alpha=0.05$ while the analyses of data were presented through SAS and SPSS. General Linear Model (GLM), post ANOVA and Least Significant Difference (LSD) were also used. Conclusion: The study revealed that an average student in Senior High School of the Upper East Region can not pass in computer subject. The research further revealed that gender has no influence on the level of computer knowledge of a student. This indicates that the level of computer knowledge of males and females is not significantly different.
\end{abstract}

Key words: Computer knowledge, senior high school, variance, ANOVA, grade, hypothesis, percentage, gender

\section{INTRODUCTION}

Computers are powerful educational tools that when properly employed will undoubtedly transform Ghana educational system by changing the contents of education and the nature of learning processes in Senior Secondary Schools in Ghana. Computers have the potential to help students to solve problems, think for themselves and collaborate with others. Some critics of educational technology have drawn conclusions for current educational technology based upon previous technologies. Others have argued that technology will never influence learning Oppenheimer' Postman, Tyack and Cuban, Clark ${ }^{[1,3-5]}$. These criticisms have been the catalyst for research into instructional methods and educational technology, as they must be linked by the very nature of education Kozma ${ }^{[2]}$. Computer science is a sub set of integrated science which is made up of introductory biology, physics, agriculture, chemistry and computer in senior high schools in Ghana.

Students completing senior high schools are therefore not fully assessed on basic computer knowledge as it forms a very small integral part of their external assessment in integrated science. A student with no computer knowledge can still make a very good grade in integrated science.

Looking at the importance of computers in this modern World has necessitated the need to assess the level of computer knowledge a student completing senior high school acquires before completion.

This study then wish to determine the level of computer knowledge a senior high school student acquires before completion, establish the differences in computer knowledge of senior high schools students across districts, establish if any of the differences in computer knowledge between males and females of senior high schools, establish if the presence of a computer laboratory has got an influence on level of computer knowledge in senior high schools and lastly generate data for future research.

Research hypothesis: Attempts were made to test the following hypotheses:

Hypothesis one: Districts versus Districts

$\mathrm{H}_{\mathrm{o} 1}$ : There is no significant difference in the level of computer knowledge across districts of the Upper East Region.

Hypothesis Two: Males versus Females

Corresponding Author: Oladejo, N.K., Department of Applied Mathematics and Computer Science, University for Development Studies, Navrongo, Ghana 
$\mathrm{H}_{02}$ : There is no significant difference in the level of computer knowledge between Males and Females.

Hypothesis three: Schools with computer laboratory versus Schools without computer laboratory

$\mathrm{H}_{03}$ : Students from schools with computer laboratory and student from schools without computer laboratory have the same level of computer knowledge.

Historical background on introduction of computers and ICT into senior secondary schools (senior high schools) in Ghana: The application of Information and Communication Technology (ICT) in schools is perceived as a means for transforming teaching and learning processes and has thus been met with significant enthusiasm. The developing world also perceives ICT as a tool that will promote socioeconomic, political and sustainable development. This perception underpins the introduction of computers and the internet in some secondary schools in Ghana.

Computer literacy is not an optional luxury but a fundamental part of the development needs of the school and of the country as a whole. It is a key to the goal of improving performance on the West African Examination Council (WAEC) exams, notably in Math, Integrated science and English. It can be a useful educational tool for all areas of the syllabus.

Computer literacy advances best not by copying what others have done elsewhere but in finding solutions appropriate to local circumstances. So for example, instead of training students on one particular word processor such as Microsoft Word, the goal is to give students a broad based understanding of word processors and the Graphical User Interfaces (GUIs) behind them. Computer literacy should be a hands-on activity. The students' primary focus of attention should be on the computers, not on the instructor.

Education policymakers in Ghana have hailed the introduction of Information and Communication Technology (ICT) in Ghanaian secondary schools as a remarkable step that will contribute to knowledge production, communication and information sharing among students and teachers in the school system. This perception stems from assertions in the literature about the benefits that come with ICT literacy in schools ${ }^{[13,14]}$ points out that ICT is a transformative tool and its full integration into the school systems is necessary to prepare students for the information society they will inherit. Contrary to the promising notion of ICT as a means of knowledge production, numerous scholars have highlighted the need to address the numerous problems that the introduction of ICT will bring.

These issues include: lack of adequate planning for implementation of $\mathrm{ICT}^{[7]}$; inadequate teacher training, inequalities in ICT distribution ${ }^{[9,10]}$; lack of information regarding the distribution of ICT; low levels of literacy in general and lack of relevant content and technology applications to meet the needs of diverse societies ${ }^{[12,14]}$.

Educational policy makers, Non-Governmental Organizations (NGO), bilateral and multilateral donor organizations and school administrators are making the collective efforts to promote ICT in Ghanaian secondary schools. Because of the efforts of NGOs and donor organizations in particular, ICT facilities have extended to some schools.

The National ICT Policy and Plan Development Committee met with the President and members of the National House of Chiefs on Thursday, the 28th of November 2002 as part of the National Consultative exercise aimed at developing an ICT-driven socioeconomic development policy and plan. During the meeting some of the key comments and observations made by chiefs are the following:

There is no doubt that ICT could play a major role in facilitating Ghana's development. There is a need for the country to embrace ICT if it is to achieve its developmental goals in the new information age.

The Ghana ICT for accelerated development process is extremely important and this could lead to the reconstruction of the economy.

The nation's successes in pursuing an ICT-led development agenda will to a large extend depend on the youths. The youths should therefore be equipped with the necessary skills to help them develop and move the nation forward. Basic literacy of the population will be playing a key role in the ICT for development process. There is therefore the need to address issues relating to the illiteracy rate of the country. The countries that have developed made it partly through high literacy rates of their populations. The Malaysian and Singaporean success story can to some extent be attributed to those nation's high literacy rates and skilled manpower.

Population of the study: The research covered seven districts in the Upper East Region. Name of selected school, district and location in each region are shown in Table 2, in which the total population is 140 students.

Sampling techniques: Two sampling techniques (stratified sampling and multistage sampling) were used in the sampling process. The whole sampling process was randomly done. No particular school was chosen for a particular purpose. All schools were considered equal in terms of infrastructures and teachers. 
Instrumentation: Only primary data was collected as there was no past record on the performance of students in computer in schools. This was due to the fact that computer was not an independent subject in Senior High Schools. The primary data was collected using an appropriate designed questionnaire.

Validation of the instrument: The selection of the schools and the students was purely random. All schools had equal opportunity of being selected. All form three students irrespective of their course and class had equal chances of selection. The sampling unit was obtained by just randomly calling any form three students.

Data analysis procedure: Data collected was coded and entered into SAS and SPSS where all the analyses were done. All hypothesis were tested at the $95 \%$ confident interval (Significant level of $\alpha=0.05$ ). If the calculated significance is less than the $\alpha=0.05$, then we fail to accept the null hypothesis $\left(\mathrm{H}_{\mathrm{o}}\right)$, otherwise the alternative hypothesis $\left(\mathrm{H}_{1}\right)$ is rejected in favor of the null hypothesis.

The tools that will be used during the analysis will include Analysis of Variance (ANOVA), Student TTest and Post ANOVA.

General description of variables: The data collected were coded and entered into excel. It was then transported into SPSS and SAS where appropriate analyses were made. The data collected was coded under 13 variables. The variables and their respective number of levels and meaning are displayed in the Table 12 data below.

Description of variables: The marks obtained by individual students in the test conducted during the data collection process were marked out of 100 . The new West African Senior School Certificate Examination (WASSCE) grading system is displayed in Table 9 and 10 below. Most analysis will be in reference to this grading system. (Source: http://www.ghanawaec.org)

\section{Preliminary analysis:}

General performance: The research conducted revealed that the average Senior High School student in the Upper East Region will score about $31 \%$ which by the new West African Senior School Certificate Examination (WASSCE) grading system is equivalent to $F_{9}$ (Failure). This is an indication that the general performance was very poor and all stakeholders who mater in terms of computer teaching in Senior High Schools, especially in the Upper East Region should sit-up.

The general performance of the 140 students sampled in term of the new West African Senior School Certificate Examination (WASSCE) grading system, is displayed in Table 9.

From Table 9 below, as much as 107 students representing $76.4 \%$ of the total sample size failed, by the new West African Senior School Certificate Examination (WASSE) grading system. This leaves only 33 students representing $23.6 \%$ to be distributed among the other grades. The distribution of the grades across the districts is shown on the Table 9.

From the Table 10 below indicates that the best performance came from the Talensi-Nabdam District with the worse performance coming from the Builsa district as all students sampled from this district failed. The detailed performances with regard to the various variables are discussed below.

Performance across districts: A total of seven districts were considered in the research process. The mean marks scored by student in the various districts are displayed in Table 2.

From the Table 2 it can be seen that TalensiNabdam District recorded the highest mean score followed by Kasena-Nankana District with Builsa District scoring the least.

By the new West African Senior School Certificate Examination (WASSCE) grading system, in exception of Talensi-Nabdam district where an average SHS student can score grade $\mathrm{C}_{6}$ (Credit), an average SHS student from the other six districts will score grade $\mathrm{F}_{9}$ (Failure).

Performance based on gender: The mean mark score of males and females are displayed in Table 1 below.

Table 1: Marks of students * sex of student

\begin{tabular}{llc}
\hline Sex of student & Mean mark & Number \\
\hline Male & 32.77 & 70 \\
Female & 28.57 & 70 \\
Total & 30.67 & 140 \\
\hline
\end{tabular}

Table 2: Marks of students * district

\begin{tabular}{llc}
\hline District & Mean mark & Number \\
\hline Talensi-Nabdam District & 55.40 & 20 \\
Bolgatanga Municipal & 26.10 & 20 \\
Bongo District & 27.75 & 20 \\
Bawku West District & 25.45 & 20 \\
Bawku Municipal & 22.65 & 20 \\
Kasena-Nankana District & 39.90 & 20 \\
Builsa District & 17.45 & 20 \\
Total & 30.67 & 140 \\
\hline
\end{tabular}


J. Math. \& Stat., 5 (4): 287-297, 2009

Table 3: Marks of students * computer usage

\begin{tabular}{llc}
\hline Computer usage & Mean mark & Number \\
\hline Yes & 35.87 & 94 \\
No & 20.04 & 46 \\
Total & 30.67 & 140 \\
\hline
\end{tabular}

Table 4: Marks of students * computer lab

\begin{tabular}{llc}
\hline Computer lab & Mean mark & Number \\
\hline Yes & 34.36 & 100 \\
No & 21.45 & 40 \\
Total & 30.67 & 140 \\
\hline
\end{tabular}

Table 1 reveals that the mean mark scored by males is slightly higher than that of females even though their respective mean scores will both yield a grade of $\mathrm{F}_{9}$ (Failure). This is an indication that the general performance of both males and females in Senior High School in computer is very poor.

Frequency distribution of students based on whether they have ever used a computer before: Students were asked whether they have ever used a computer before. Their frequency distribution based on the responses they gave is displayed in Table 3 .

In the Table 3 , it is clear that about $67 \%$ of the students sampled out for this research have ever used a computer as against $33 \%$ who had never used the computer.

Performance based on accessibility to computer laboratory: Students were asked whether they had a computer laboratory or not. Table 4 display their frequency distributions and their respective mean mark scores.

Table 4 indicates that out of the 140 students sampled, 100 of them representing about $72 \%$ had access to a computer laboratory while the remaining 40 students representing about $28 \%$ did not have a computer lab in their respective schools. Their mean marks in term of accessibility are displayed in Table 4.

Table 4 shows that students who have access to computer laboratory perform slightly better than students with no access to a computer laboratory. Even though the mean mark scored by either category of students is nothing to write home about, there is still a possible indication that availability of computer laboratory to students may be a contributive factor to their knowledge in computer. This will be tested in the further analysis to verify if the availability of computer laboratories in schools is a real factor of computer knowledge.
Table 5: Marks of students * practical work

\begin{tabular}{llc}
\hline Practical work & Mean mark & Number \\
\hline Yes & 37.29 & 80 \\
No & 21.85 & 60 \\
Total & 30.67 & 140 \\
\hline
\end{tabular}

Table 6: Marks of students * no. of computer teachers

\begin{tabular}{llc}
\hline No. of computer teachers & Mean mark & Number \\
\hline 0 & 17.45 & 20 \\
1 & 27.75 & 20 \\
2 & 24.05 & 40 \\
4 & 47.65 & 40 \\
5 & 26.10 & 20 \\
Total & 30.67 & 140 \\
\hline
\end{tabular}

Performance based on practical lessons: During the research it came out that even though some schools had a computer laboratory, they did not give their student the opportunity to visit the laboratory for practical lessons. Table 5 below gives a frequency distribution and their respective categorical mean mark scores.

There is an indication that $57 \%$ of the 140 students sampled have practical lessons as against $43 \%$ who did not have practical lessons. Comparing the percentage number of students, who had practical lessons to the percentage number of students that had access to a computer laboratory, shows that it had reduced from 72 to $57 \%$. This is a clear indication that some students are been denied their right to practical lessons even though they paid to use the facility. The performance of the students in each category is displayed as shown in Table 5.

Performance of both categories of students was poor as can be seen from Table 5. An average student who attends practical computer lesson will score about $37 \%$ which will yield grade $\mathrm{F}_{9}$ (Failure). The least said about the students who did not practical lessons the better. Table 5 and 9 give reasons to believe that having practical lessons will improve a student's knowledge in computer. This may be due to the assertion by many people that 'practice makes man perfect'.

Performance based on the number of computer teachers: Students were asked to indicate the number of computer teachers they had in their respective schools. Their responses are displayed in Table 6 below. Their frequencies and average mark score of each category are put together on the same chart.

From Table 6, it can be seen that 40 students had 2 teachers in their school and another 40 had 4 teachers in their schools. 20 students did not have a computer teacher in their school. The highest mean mark score came from the category of students who had 4 computer teachers, with the lowest mean mark score recorded by the category of students with no computer teacher. It 
might be expected that the more the number of computer teachers in a school, the better the knowledge they impact as the teacher to student ratio will be low. But it must also be noted that individual differences among the teachers, in term of method, skill and knowledge are possible factors that may sway this pattern.

Performance based on time spent per practical lesson: Table 7 displays the performance of students based on the amount of time spent per practical lesson.

It is believed that the more time spent on practical lessons the better the performance of students in computer. It is therefore not surprising that this pattern has been displayed by the above chart with the category of students who spent one hour per practical lesson recording the highest mean mark while the category of students who do not have practical lessons scored the least mean mark. By the new West African Senior School Certificate Examination (WASSCE) grading system, an average student who spends one hour per practical lesson will score grade $\mathrm{E}_{8}$ (pass). This could be an indication that the amount of time spent per practical lessons had an influence on the general performance in computer.

Performance based on number of students per a computer: Students were required to indicate the number of them that use one computer at a time during practical lessons. Their frequency distribution and mean mark score for each category is displayed on the Table 8 .

The pattern indicated by Table 8 shows that the lower the ratio the better the performance as the mean mark score for the category of students who sit two to a computer is the highest. As usual the mean mark of students who do not have practical lessons is lowest. This could be due to the fact that as the ratio becomes smaller, it gives more opportunity to the students to have access to the computer thereby increasing their understanding.
Further analysis: During the preliminary analysis it was suspected that some factors were responsible for the poor performance. This section will seek to further analyze these factors to confirm or disprove the suspected claims such as males perform better than females, category of students who have access to a computer laboratory perform better than the category of students who do not have access to a computer laboratory and that the district in which a student attends school has an influence on his/her performance. There were numerous factors that were suspected to have an influence on performance of students in computer as discussed in the preliminary analysis. But for the purpose of this study, only the availability of a computer laboratory, gender of the student and the district to which a student belongs will be considered.

\begin{tabular}{llc}
\multicolumn{2}{l}{ Table 7: Marks of students $*$ hours per visit } \\
\hline Hours per visit & Mean mark & Number \\
\hline 30 min & 33.83 & 40 \\
$1 \mathrm{~h}$ & 40.75 & 40 \\
Others & 21.85 & 60 \\
Total & 30.67 & 140 \\
\hline
\end{tabular}

Table 8: Marks of students * ratio of student to computer

\begin{tabular}{llc}
\hline Ratio of student to computer & Mean mark & Number \\
\hline 1-to-2 & 41.58 & 40 \\
1-to-5 & 33.00 & 40 \\
Others & 21.85 & 60 \\
Total & 30.67 & 140 \\
\hline
\end{tabular}

Table 9: Grade of students (remark)

\begin{tabular}{|c|c|c|c|c|}
\hline Grade (remark) & Frequency & Percent & Valid (\%) & Cumulative (\%) \\
\hline$\overline{\mathrm{F}_{9}(\text { fail) }}$ & 107 & 76.4 & 76.4 & 76.4 \\
\hline $\mathrm{E}_{8}$ (pass) & 10 & 7.1 & 7.1 & 83.6 \\
\hline $\mathrm{D}_{7}$ (pass) & 4 & 2.9 & 2.9 & 86.4 \\
\hline $\mathrm{C}_{6}$ (credit) & 6 & 4.3 & 4.3 & 90.7 \\
\hline $\mathrm{C}_{5}$ (credit) & 3 & 2.1 & 2.1 & 92.9 \\
\hline $\mathrm{C}_{4}$ (credit) & 3 & 2.1 & 2.1 & 95.0 \\
\hline $\mathrm{B}_{3}$ (good) & 1 & 0.7 & 0.7 & 95.7 \\
\hline $\mathrm{B}_{2}$ (very good) & 2 & 1.4 & 1.4 & 97.1 \\
\hline $\mathrm{A}_{1}$ (excellent) & 4 & 2.9 & 2.9 & 100.0 \\
\hline Total & 140 & 100.0 & 100.0 & \\
\hline
\end{tabular}

Table 10: Grade of students (remark) * district cross tabulation

\begin{tabular}{|c|c|c|c|c|c|c|c|c|}
\hline \multirow[b]{2}{*}{$\begin{array}{l}\text { Grade of students } \\
\text { (Remark) }\end{array}$} & \multicolumn{7}{|c|}{ Districts } & \multirow[b]{2}{*}{ Total } \\
\hline & $\begin{array}{l}\text { Talensi-Nabdam } \\
\text { District }\end{array}$ & $\begin{array}{l}\text { Bolgatanga } \\
\text { Municipal }\end{array}$ & $\begin{array}{l}\text { Bongo } \\
\text { District }\end{array}$ & $\begin{array}{l}\text { Bawku } \\
\text { District }\end{array}$ & $\begin{array}{l}\text { Bawku } \\
\text { West District }\end{array}$ & $\begin{array}{l}\text { Kasena-nankana } \\
\text { Municipal }\end{array}$ & $\begin{array}{l}\text { Builsa } \\
\text { District }\end{array}$ & \\
\hline F9 (fail) & 5 & 18 & 17 & 18 & 17 & 12 & 20 & 107 \\
\hline E8 (pass) & 2 & 1 & 3 & & 2 & 2 & & 10 \\
\hline D7 (pass) & 2 & 1 & & & & 1 & & 4 \\
\hline C6 (credit) & 2 & & & 1 & & 3 & & 6 \\
\hline C5 (credit) & 1 & & & & 1 & 1 & & 3 \\
\hline C4 (credit) & 3 & & & & & & & 3 \\
\hline B3 (good) & & & & 1 & & & & 1 \\
\hline B2 (very good) & 2 & & & & & & & 2 \\
\hline A1 (excellent) & 3 & & & & & 1 & & 4 \\
\hline Total & 20 & 20 & 20 & 20 & 20 & 20 & 20 & 140 \\
\hline
\end{tabular}


J. Math. \& Stat., 5 (4): 287-297, 2009

Table 11: Grade of students (remark)* computer lab cross-tabulation

\begin{tabular}{|c|c|c|c|}
\hline \multirow[b]{2}{*}{ Grade of students (remark) } & \multicolumn{2}{|c|}{ Computer lab } & \multirow[b]{2}{*}{ Total } \\
\hline & Yes & No & \\
\hline F9 (fail) & 69 & 38 & 107 \\
\hline E8 (pass) & 10 & & 10 \\
\hline D7 (pass) & 4 & & 4 \\
\hline C6 (credit) & 5 & 1 & 6 \\
\hline C5 (credit) & 3 & & 3 \\
\hline C4 (credit) & 3 & & 3 \\
\hline B3 (good) & & 1 & 1 \\
\hline B2 (very good) & 2 & & 2 \\
\hline A1 (excellent) & 4 & & 4 \\
\hline Total & 100 & 40 & 140 \\
\hline
\end{tabular}

Table 12: Data

\begin{tabular}{|c|c|c|c|c|c|c|c|c|c|c|c|c|}
\hline Id & Sex & Age & District & RG of RES & Use Comp & Comp Lab & Prt Wrks & Hours per vist & Ratio & No. Comp Tchs & Tchs Pfs & Mark \\
\hline 120 & 1 & 18 & 1 & UER & 1 & 1 & 1 & 2 & 2 & 4 & 2 & 76 \\
\hline 110 & 2 & 18 & 1 & UER & 1 & 1 & 1 & 2 & 2 & 4 & 3 & 27 \\
\hline 112 & 1 & 19 & 1 & UER & 1 & 1 & 1 & 2 & 2 & 4 & 3 & 58 \\
\hline 111 & 1 & 18 & 1 & UER & 1 & 1 & 1 & 2 & 2 & 4 & 2 & 88 \\
\hline 113 & 1 & 20 & 1 & BAR & 1 & 1 & 1 & 2 & 2 & 4 & 1 & 81 \\
\hline 114 & 1 & 20 & 1 & UER & 1 & 1 & 1 & 2 & 2 & 4 & 2 & 80 \\
\hline 115 & 1 & 19 & 1 & NR & 1 & 1 & 1 & 2 & 2 & 4 & 4 & 48 \\
\hline 116 & 1 & 17 & 1 & UER & 1 & 1 & 1 & 2 & 2 & 4 & 1 & 24 \\
\hline 117 & 1 & 18 & 1 & UER & 1 & 1 & 1 & 2 & 2 & 4 & 2 & 60 \\
\hline 118 & 1 & 20 & 1 & UER & 1 & 1 & 1 & 2 & 2 & 4 & 4 & 78 \\
\hline 109 & 2 & 18 & 1 & UER & 1 & 1 & 1 & 2 & 2 & 4 & 2 & 42 \\
\hline 108 & 2 & 19 & 1 & UER & 1 & 1 & 1 & 2 & 2 & 4 & 2 & 57 \\
\hline 107 & 2 & 18 & 1 & UER & 1 & 1 & 1 & 2 & 2 & 4 & 1 & 25 \\
\hline 106 & 2 & 18 & 1 & ASR & 1 & 1 & 1 & 2 & 2 & 4 & 2 & 51 \\
\hline 105 & 2 & 19 & 1 & UER & 1 & 1 & 1 & 2 & 2 & 4 & 1 & 51 \\
\hline 104 & 2 & 18 & 1 & UER & 1 & 1 & 1 & 2 & 2 & 4 & 2 & 66 \\
\hline 103 & 2 & 19 & 1 & UER & 1 & 1 & 1 & 2 & 2 & 4 & 4 & 31 \\
\hline 102 & 2 & 18 & 1 & UWR & 1 & 1 & 1 & 2 & 2 & 4 & 4 & 67 \\
\hline 101 & 2 & 19 & 1 & NR & 1 & 1 & 1 & 2 & 2 & 4 & 1 & 31 \\
\hline 119 & 1 & 19 & 1 & UER & 1 & 1 & 1 & 2 & 2 & 4 & 3 & 67 \\
\hline 100 & 1 & 25 & 2 & UER & 1 & 1 & 1 & 2 & 3 & 5 & 2 & 39 \\
\hline 81 & 1 & 22 & 2 & UER & 1 & 1 & 1 & 2 & 3 & 5 & 4 & 28 \\
\hline 82 & 1 & 20 & 2 & UER & 1 & 1 & 1 & 2 & 3 & 5 & 5 & 1 \\
\hline 83 & 2 & 19 & 2 & UER & 1 & 1 & 1 & 2 & 3 & 5 & 4 & 9 \\
\hline 84 & 1 & 19 & 2 & UER & 1 & 1 & 1 & 2 & 3 & 5 & 5 & 31 \\
\hline 85 & 2 & 18 & 2 & UER & 1 & 1 & 1 & 2 & 3 & 5 & 1 & 34 \\
\hline 86 & 2 & 22 & 2 & UER & 1 & 1 & 1 & 2 & 3 & 5 & 4 & 9 \\
\hline 87 & 2 & 17 & 2 & UER & 1 & 1 & 1 & 2 & 3 & 5 & 1 & 40 \\
\hline 88 & 2 & 19 & 2 & UER & 1 & 1 & 1 & 2 & 3 & 5 & 2 & 15 \\
\hline 89 & 2 & 19 & 2 & UER & 1 & 1 & 1 & 2 & 3 & 5 & 4 & 26 \\
\hline 90 & 2 & 20 & 2 & UER & 1 & 1 & 1 & 2 & 3 & 5 & 1 & 15 \\
\hline 91 & 1 & 25 & 2 & UER & 1 & 1 & 1 & 2 & 3 & 5 & 5 & 35 \\
\hline 92 & 2 & 19 & 2 & ASR & 1 & 1 & 1 & 2 & 3 & 5 & 1 & 34 \\
\hline 93 & 2 & 18 & 2 & ASR & 1 & 1 & 1 & 2 & 3 & 5 & 2 & 33 \\
\hline 94 & 1 & 19 & 2 & ASR & 1 & 1 & 1 & 2 & 3 & 5 & 2 & 33 \\
\hline 96 & 1 & 29 & 2 & UER & 1 & 1 & 1 & 2 & 3 & 5 & 1 & 33 \\
\hline 97 & 1 & 19 & 2 & UWR & 1 & 1 & 1 & 2 & 3 & 5 & 2 & 54 \\
\hline 98 & 1 & 24 & 2 & UER & 1 & 1 & 1 & 2 & 3 & 5 & 5 & 20 \\
\hline 99 & 2 & 20 & 2 & UWR & 1 & 1 & 1 & 2 & 3 & 5 & 3 & 16 \\
\hline 95 & 1 & 20 & 2 & UER & 1 & 1 & 1 & 2 & 3 & 5 & 3 & 17 \\
\hline 80 & 2 & 18 & 3 & UER & 1 & 1 & 1 & 1 & 2 & 1 & 5 & 25 \\
\hline 61 & 1 & 20 & 3 & UER & 1 & 1 & 1 & 1 & 2 & 1 & 5 & 33 \\
\hline 62 & 1 & 18 & 3 & UER & 1 & 1 & 1 & 1 & 2 & 1 & 1 & 37 \\
\hline 63 & 2 & 20 & 3 & UER & 1 & 1 & 1 & 1 & 2 & 1 & 3 & 43 \\
\hline 64 & 2 & 20 & 3 & UER & 1 & 1 & 1 & 1 & 2 & 1 & 1 & 34 \\
\hline 65 & 2 & 18 & 3 & UER & 1 & 1 & 1 & 1 & 2 & 1 & 5 & 39 \\
\hline 66 & 1 & 24 & 3 & UER & 1 & 1 & 1 & 1 & 2 & 1 & 2 & 47 \\
\hline 67 & 2 & 19 & 3 & UER & 1 & 1 & 1 & 1 & 2 & 1 & 5 & 10 \\
\hline
\end{tabular}


J. Math. \& Stat., 5 (4): 287-297, 2009

\begin{tabular}{|c|c|c|c|c|c|c|c|c|c|c|c|c|}
\hline 68 & 1 & 20 & 3 & UER & 1 & 1 & 1 & 1 & 2 & 1 & 4 & 23 \\
\hline 69 & 1 & 18 & 3 & UER & 1 & 1 & 1 & 1 & 2 & 1 & 3 & 12 \\
\hline 70 & 1 & 18 & 3 & UER & 1 & 1 & 1 & 1 & 2 & 1 & 1 & 14 \\
\hline 71 & 2 & 20 & 3 & UER & 1 & 1 & 1 & 1 & 2 & 1 & 5 & 27 \\
\hline 72 & 2 & 21 & 3 & UER & 1 & 1 & 1 & 1 & 2 & 1 & 3 & 20 \\
\hline 73 & 1 & 22 & 3 & UER & 1 & 1 & 1 & 1 & 2 & 1 & 5 & 47 \\
\hline 74 & 1 & 17 & 3 & UER & 1 & 1 & 1 & 1 & 2 & 1 & 5 & 38 \\
\hline 75 & 2 & 17 & 3 & UER & 1 & 1 & 1 & 1 & 2 & 1 & 3 & 34 \\
\hline 76 & 2 & 23 & 3 & UER & 1 & 1 & 1 & 1 & 2 & 1 & 5 & 23 \\
\hline 77 & 1 & 21 & 3 & UER & 1 & 1 & 1 & 1 & 2 & 1 & 5 & 17 \\
\hline 78 & 1 & 20 & 3 & UER & 1 & 1 & 1 & 1 & 2 & 1 & 2 & 19 \\
\hline 79 & 2 & 19 & 3 & UER & 1 & 1 & 1 & 1 & 2 & 1 & 5 & 13 \\
\hline 41 & 2 & 18 & 4 & UER & 2 & 2 & 2 & 4 & 4 & 2 & 3 & 25 \\
\hline 42 & 1 & 22 & 4 & UER & 2 & 2 & 2 & 4 & 4 & 2 & 1 & 59 \\
\hline 43 & 1 & 18 & 4 & UER & 2 & 2 & 2 & 4 & 4 & 2 & 3 & 25 \\
\hline 44 & 2 & 19 & 4 & UER & 2 & 2 & 2 & 4 & 4 & 2 & 3 & 20 \\
\hline 45 & 1 & 23 & 4 & UER & 2 & 2 & 2 & 4 & 4 & 2 & 3 & 15 \\
\hline 46 & 1 & 25 & 4 & UER & 2 & 2 & 2 & 4 & 4 & 2 & 1 & 10 \\
\hline 47 & 1 & 24 & 4 & UER & 2 & 2 & 2 & 4 & 4 & 2 & 4 & 7 \\
\hline 48 & 1 & 20 & 4 & UER & 1 & 2 & 2 & 4 & 4 & 2 & 2 & 71 \\
\hline 49 & 2 & 18 & 4 & UER & 2 & 2 & 2 & 4 & 4 & 2 & 1 & 11 \\
\hline 50 & 2 & 19 & 4 & UER & 2 & 2 & 2 & 4 & 4 & 2 & 2 & 24 \\
\hline 51 & 1 & 19 & 4 & UER & 2 & 2 & 2 & 4 & 4 & 2 & 1 & 17 \\
\hline 52 & 2 & 18 & 4 & UER & 2 & 2 & 2 & 4 & 4 & 2 & 2 & 30 \\
\hline 53 & 2 & 19 & 4 & ASR & 1 & 2 & 2 & 4 & 4 & 2 & 1 & 12 \\
\hline 54 & 1 & 22 & 4 & UER & 2 & 2 & 2 & 4 & 4 & 2 & 4 & 20 \\
\hline 55 & 1 & 21 & 4 & UER & 2 & 2 & 2 & 4 & 4 & 2 & 3 & 31 \\
\hline 56 & 2 & 19 & 4 & UER & 1 & 2 & 2 & 4 & 4 & 2 & 2 & 33 \\
\hline 57 & 2 & 21 & 4 & UER & 1 & 2 & 2 & 4 & 4 & 2 & 3 & 21 \\
\hline 58 & 2 & 18 & 4 & UER & 2 & 2 & 2 & 4 & 4 & 2 & 2 & 18 \\
\hline 59 & 1 & 18 & 4 & UER & 1 & 2 & 2 & 4 & 4 & 2 & 5 & 36 \\
\hline 60 & 2 & 17 & 4 & UER & 2 & 2 & 2 & 4 & 4 & 2 & 3 & 24 \\
\hline 21 & 2 & 16 & 5 & UER & 1 & 1 & 2 & 4 & 4 & 2 & 2 & 31 \\
\hline 22 & 1 & 20 & 5 & UER & 2 & 1 & 2 & 4 & 4 & 2 & 3 & 12 \\
\hline 23 & 1 & 20 & 5 & UER & 2 & 1 & 2 & 4 & 4 & 2 & 4 & 7 \\
\hline 24 & 2 & 16 & 5 & UER & 1 & 1 & 2 & 4 & 4 & 2 & 3 & 15 \\
\hline 25 & 2 & 17 & 5 & NR & 1 & 1 & 2 & 4 & 4 & 2 & 5 & 9 \\
\hline 26 & 2 & 17 & 5 & UER & 1 & 1 & 2 & 4 & 4 & 2 & 5 & 38 \\
\hline 27 & 2 & 18 & 5 & UER & 2 & 1 & 2 & 4 & 4 & 2 & 4 & 9 \\
\hline 28 & 1 & 18 & 5 & UER & 1 & 1 & 2 & 4 & 4 & 2 & 2 & 60 \\
\hline 29 & 2 & 16 & 5 & UER & 1 & 1 & 2 & 4 & 4 & 2 & 2 & 32 \\
\hline 30 & 1 & 21 & 5 & UER & 2 & 1 & 2 & 4 & 4 & 2 & 1 & 9 \\
\hline 31 & 1 & 14 & 5 & UER & 2 & 1 & 2 & 4 & 4 & 2 & 5 & 26 \\
\hline 32 & 2 & 16 & 5 & UER & 1 & 1 & 2 & 4 & 4 & 2 & 1 & 46 \\
\hline 33 & 1 & 19 & 5 & UER & 2 & 1 & 2 & 4 & 4 & 2 & 1 & 8 \\
\hline 34 & 1 & 19 & 5 & UER & 2 & 1 & 2 & 4 & 4 & 2 & 3 & 40 \\
\hline 35 & 1 & 19 & 5 & NR & 2 & 1 & 2 & 4 & 4 & 2 & 5 & 7 \\
\hline 36 & 1 & 19 & 5 & UER & 1 & 1 & 2 & 4 & 4 & 2 & 4 & 28 \\
\hline 37 & 1 & 20 & 5 & UER & 2 & 1 & 2 & 4 & 4 & 2 & 3 & 16 \\
\hline 38 & 2 & 17 & 5 & UER & 1 & 1 & 2 & 4 & 4 & 2 & 3 & 9 \\
\hline 39 & 2 & 18 & 5 & UER & 2 & 1 & 2 & 4 & 4 & 2 & 4 & 17 \\
\hline 40 & 2 & 16 & 5 & UER & 2 & 1 & 2 & 4 & 4 & 2 & 2 & 34 \\
\hline 20 & 1 & 17 & 6 & UER & 1 & 1 & 1 & 1 & 3 & 5 & 3 & 58 \\
\hline 19 & 1 & 15 & 6 & UER & 1 & 1 & 1 & 1 & 3 & 2 & 3 & 13 \\
\hline 18 & 1 & 21 & 6 & UER & 1 & 1 & 1 & 1 & 3 & 4 & 4 & 33 \\
\hline 17 & 1 & 19 & 6 & NR & 1 & 1 & 1 & 1 & 3 & 4 & 4 & 23 \\
\hline 16 & 1 & 20 & 6 & CR & 1 & 1 & 1 & 1 & 3 & 4 & 4 & 81 \\
\hline 15 & 1 & 19 & 6 & UER & 2 & 1 & 1 & 1 & 3 & 4 & 5 & 36 \\
\hline 14 & 1 & 22 & 6 & UER & 1 & 1 & 1 & 1 & 3 & 4 & 3 & 34 \\
\hline 13 & 1 & 18 & 6 & UER & 1 & 1 & 1 & 1 & 3 & 4 & 3 & 13 \\
\hline 12 & 1 & 19 & 6 & UER & 1 & 1 & 1 & 1 & 3 & 4 & 5 & 51 \\
\hline 11 & 2 & 16 & 6 & UER & 2 & 1 & 1 & 1 & 3 & 4 & 4 & 36 \\
\hline 10 & 2 & 20 & 6 & GR & 2 & 1 & 1 & 1 & 3 & 4 & 5 & 33 \\
\hline 9 & 2 & 18 & 6 & UER & 1 & 1 & 1 & 1 & 3 & 4 & 4 & 41 \\
\hline \multirow[t]{2}{*}{8} & 2 & 18 & 6 & UER & 1 & 1 & 1 & 1 & 3 & 4 & 1 & 587 \\
\hline & 2 & 17 & 6 & UER & 1 & 1 & 1 & 1 & 3 & 4 & 2 & 55 \\
\hline 6 & 2 & 21 & 6 & UER & 1 & 1 & 1 & 1 & 3 & 4 & 4 & 44 \\
\hline 5 & 2 & 17 & 6 & UER & 1 & 1 & 1 & 1 & 3 & 4 & 5 & 63 \\
\hline 4 & 2 & 18 & 6 & UER & 1 & 1 & 1 & 1 & 3 & 4 & 1 & 34 \\
\hline
\end{tabular}




\begin{tabular}{|c|c|c|c|c|c|c|c|c|c|c|c|c|}
\hline 3 & 2 & 17 & 6 & UER & 2 & 1 & 1 & 1 & 3 & 4 & 4 & 34 \\
\hline 2 & 1 & 23 & 6 & UER & 1 & 1 & 1 & 1 & 3 & 4 & 1 & 33 \\
\hline 1 & 2 & 19 & 6 & UER & 1 & 1 & 1 & 1 & 3 & 4 & 2 & 25 \\
\hline 140 & 1 & 19 & 7 & UER & 2 & 2 & 2 & 4 & 4 & 0 & 0 & 13 \\
\hline 139 & 2 & 20 & 7 & UER & 1 & 2 & 2 & 4 & 4 & 0 & 0 & 28 \\
\hline 138 & 2 & 19 & 7 & UER & 2 & 2 & 2 & 4 & 4 & 0 & 0 & 15 \\
\hline 137 & 1 & 18 & 7 & UER & 1 & 2 & 2 & 4 & 4 & 0 & 0 & 20 \\
\hline 136 & 1 & 19 & 7 & UER & 1 & 2 & 2 & 4 & 4 & 0 & 0 & 14 \\
\hline 135 & 2 & 17 & 7 & UER & 2 & 2 & 2 & 4 & 4 & 0 & 0 & 12 \\
\hline 134 & 2 & 19 & 7 & UER & 2 & 2 & 2 & 4 & 4 & 0 & 0 & 12 \\
\hline 133 & 2 & 18 & 7 & UER & 2 & 2 & 2 & 4 & 4 & 0 & 0 & 25 \\
\hline 132 & 2 & 17 & 7 & UER & 2 & 2 & 2 & 4 & 4 & 0 & 0 & 20 \\
\hline 131 & 2 & 21 & 7 & UER & 2 & 2 & 2 & 4 & 4 & 0 & 0 & 13 \\
\hline 130 & 1 & 21 & 7 & UER & 2 & 2 & 2 & 4 & 4 & 0 & 0 & 22 \\
\hline 129 & 1 & 22 & 7 & UER & 2 & 2 & 2 & 4 & 4 & 0 & 0 & 30 \\
\hline 128 & 2 & 18 & 7 & UER & 2 & 2 & 2 & 4 & 4 & 0 & 0 & 12 \\
\hline 127 & 1 & 18 & 7 & UER & 2 & 2 & 2 & 4 & 4 & 0 & 0 & 17 \\
\hline 126 & 1 & 20 & 7 & UER & 2 & 2 & 2 & 4 & 4 & 0 & 0 & 6 \\
\hline 125 & 1 & 19 & 7 & UER & 2 & 2 & 2 & 4 & 4 & 0 & 0 & 14 \\
\hline 124 & 2 & 19 & 7 & UER & 1 & 2 & 2 & 4 & 4 & 0 & 0 & 25 \\
\hline 123 & 1 & 19 & 7 & UER & 2 & 2 & 2 & 4 & 4 & 0 & 0 & 8 \\
\hline 122 & 1 & 19 & 7 & UER & 2 & 2 & 2 & 4 & 4 & 0 & 0 & 33 \\
\hline 121 & 2 & 18 & 7 & UER & 2 & 2 & 2 & 4 & 4 & 0 & 0 & 10 \\
\hline
\end{tabular}

Test of hypothesis: All hypotheses were tested using ANOVA in the General Linear Model procedure (GLM). The level of significance is $\alpha=0.05$.

Rejection region: Reject the null hypothesis in favor of the alternative hypothesis if the probability associated with the F-value $(\mathrm{pr}>\mathrm{F})$ is less than $\alpha=0.05$, otherwise we accept the null hypothesis.

\section{Hypothesis one: Districts versus districts:}

Ho: There is no significant difference in the level of computer knowledge across districts of the Upper East Region.

H1: There is difference in the level of computer knowledge across districts in Upper East Region.

\begin{tabular}{|c|c|c|c|c|c|}
\hline \multicolumn{6}{|c|}{$\begin{array}{l}\text { Result: } \\
\text { Output } 4.0 \\
\text { The SAS System } \\
\text { The GLM Procedure } \\
\text { Dependent variable: MARK } \\
\text { Sum of }\end{array}$} \\
\hline $\begin{array}{l}\text { Source } \\
\text { Model } \\
\text { Error } \\
\text { Corrected } \\
\text { Total }\end{array}$ & $\begin{array}{r}\text { DF } \\
6 \\
133 \\
139\end{array}$ & $\begin{array}{l}\text { Squares } \\
19850.28571 \\
29500.60000 \\
49350.88571\end{array}$ & $\begin{array}{c}\text { Mean square } \\
3308.38095 \\
221.80902\end{array}$ & $\begin{array}{l}\text { F-value } \\
14.92\end{array}$ & $\begin{array}{l}\operatorname{Pr}>\mathrm{F} \\
<0.0001\end{array}$ \\
\hline $\begin{array}{l}\text { Source } \\
\text { District }\end{array}$ & $\begin{array}{l}\text { DF } \\
6\end{array}$ & $\begin{array}{l}\text { Type III SS } \\
19850.28571\end{array}$ & $\begin{array}{l}\text { Mean Square } \\
3308.38095\end{array}$ & $\begin{array}{l}\text { F-value } \\
14.92\end{array}$ & $\begin{array}{l}\mathrm{Pr}>\mathrm{F} \\
<0.0001\end{array}$ \\
\hline
\end{tabular}

Interpretation: From the result displayed above, the $\operatorname{Pr}>\mathrm{F}$ is less than $\alpha=0.05$ (that is $0.0001<0.05$ ). This means that we do not have enough evidence to accept the null hypothesis. This is therefore an indication confirming the fact that the district in which a student is schooling has an effect on his/her performance in computer. This pattern was expected as there is no parity in terms of infrastructure and development in the districts.

Post ANOVA: Since there was an indication of a difference, another analysis was performed to find which districts were similar to each other in terms of performance. The option used for this test was Least Significant Difference (LSD) under the comparison of means. The result of the analyses is displayed below.

Output 4.1

The SAS System

The GLM Procedure

$\mathrm{t}$-Tests (LSD) for MARK

\begin{tabular}{|c|c|c|c|c|c|}
\hline \multicolumn{5}{|c|}{ Alpha } & 0.05000 \\
\hline \multicolumn{5}{|c|}{ Error degrees of freedom } & 133.00000 \\
\hline \multicolumn{5}{|c|}{ Error means square } & 221.80900 \\
\hline \multicolumn{5}{|c|}{ Critical value of $t$} & 1.97796 \\
\hline \multicolumn{5}{|c|}{ Least significant difference } & 9.31550 \\
\hline \multicolumn{6}{|c|}{ Means with the same letter are not significantly different } \\
\hline \multicolumn{6}{|c|}{ t Grouping } \\
\hline & & Mean & $\mathrm{N}$ & DISTRICT & \\
\hline & A & 55.400 & 20 & Talensi-Nabdam & \\
\hline & B & 39.900 & 20 & Kasena-Nankana District & \\
\hline & $\mathrm{C}$ & 27.750 & 20 & Bongo District & \\
\hline & $\mathrm{C}$ & & & & \\
\hline D & $\mathrm{C}$ & 26.100 & 20 & Bolgatanga Municipal & \\
\hline $\mathrm{D}$ & $\mathrm{C}$ & & & & \\
\hline $\mathrm{D}$ & $\mathrm{C}$ & 25.450 & 20 & Bawku West District & \\
\hline $\mathrm{D}$ & $\mathrm{C}$ & & & & \\
\hline $\mathrm{D}$ & $\mathrm{C}$ & 22.650 & 20 & Bawku Municipal & \\
\hline D & & & & & \\
\hline D & & 17.450 & 20 & Builsa District & \\
\hline
\end{tabular}




\section{Questionnaire: \\ University for development studies: \\ Faculty of applied sciences: \\ Navrongo campus: \\ Assessing computer knowledge in senior high schools: \\ A case study of the upper east region: \\ Please tick the box that is applicable to you \\ Part A: Personal information}

1. Sex

2. Age

3. Form

4. Region of resident

5. Have you ever used a computer?

6. At what age did you first use a computer?

7. At what level did you first use a computer?
Male Female

SHS JHS Primary Others (specify)

Part B: General assessment of computer teaching/facilities in the school

1. Do you have a computer lab in your school?

$1 \mathrm{~b}$ if no, go to no. 8

2. Do you visit the lab for practical works?

3. How often do you go there? Once a month Once every two week Once a week

Yes $\quad$ No

Yes No

Others (specify)

4. How many hours do you spend per visit?

$$
30 \mathrm{~min} \quad 1 \mathrm{~h} \quad 2 \mathrm{~h}
$$

Others (specify)

5. How many computers do you have in your lab?

6. Is the number of computers enough to satisfy each class at a time?

7. How many of you use one computer at a time?

$1-1$

Total

Functioning

Malfunctioning

Yes No

2-1 5-1 Other (specify)

8. How many computer teachers do you have?

9. Is the number adequate for the whole school?

10. How would you grade the performance of your teacher(s)

11. Do you have access to internet facilities in your school?

12. In your own view what do you think should be done to improve computer studies in your school?

Part C: General knowledge in computer

1. What is a computer?

2. Mention two uses of the computer

i.

ii.

3. Define the following:
a) Input device
b) Output device

4. List two examples each of the following
a) Input device:
b) Output device:
c) Storage device:

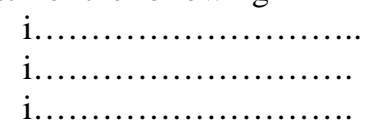

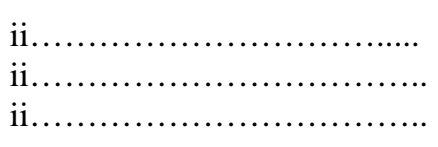

295 
5. State the full meaning of the following as applied to computer(s)
a) RAM
b) ROM
c) $\mathrm{CPU}$

6. Write one function each of the following keys on the keyboard
a) Arrow keys
b) Space bar
c) Caps lock
d) Enter

7. Arrange the following in the correct order of opening a Microsoft word window; all programs, Microsoft office, start menu, Microsoft word.
i) .
ii) .
iii)
iv)

8. Mention two Microsoft office tools.

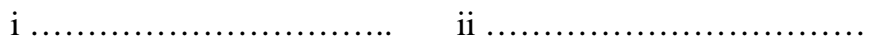

9. Arrange the following in the correct order of saving a fresh document in Microsoft office; file name, save as, file, save.
i) $\ldots \ldots \ldots \ldots \ldots . . . . .$.
ii)
iii) .
iv)

10. State the systematic order of shutting down a computer.

Thank you

Interpretation: From the result above it can be seen that the performance of students from Talensi-Nabdam district differs from the rest of the districts. The same applies to Kassena-Nankana district. Meanwhile the performance of students from Bongo District, Balgatanga Municipal, Bawku West District and Bawku were not significantly different. The same applies to Balgatanga Municipal, Bawku West District, Bawku Municipal and Builsa District.

\section{Hypothesis two: Males versus females:}

Ho: There is no significant difference in the level of computer knowledge between Males and Females.

H1: Males have a higher knowledge in computer than females.

Result

Output 4.2

The SAS System

The GLM Procedure

Dependent Variable: MARK

Sum of

\begin{tabular}{lrllll}
\hline Source & DF & Squares & Mean square & F-value & $\operatorname{Pr}>$ F \\
Model & 1 & 617.40000 & 617.40000 & 1.75 & 0.1883 \\
Error & 138 & 48733.48571 & 353.14120 & & \\
Corrected & 139 & 49350.88571 & & & \\
Total & & & & & \\
\hline \multicolumn{7}{l}{} \\
\hline Source & DF & Type III SS & Mean square & F-value & $\operatorname{Pr}>$ F \\
SEX & 1 & 617.4000000 & 617.4000000 & 1.75 & 0.1883 \\
\hline
\end{tabular}

Interpretation: From the result displayed above, the $\operatorname{Pr}>\mathrm{F}$ is greater than $\alpha=0.05$ (that is $0.1883>0.05$ ). This means that we do not have enough evidence to reject the null hypothesis that there is no significant difference in the level of computer knowledge between Males and Females. We can therefore say that the knowledge of a student is independent on the gender of the student. In other words, it implies that you do not have to be a male or female to have in-depth knowledge in computer.

Hypothesis three: Schools with computer laboratory versus schools without computer laboratory:

Ho: Students from schools with computer laboratory and student from schools without computer laboratory have the same level of computer knowledge.

H1: Students from schools with computer laboratory have higher computer knowledge than students from schools without computer laboratory ( Table 11).

Result

Output 4.3

The SAS System

The GLM Procedure

Dependent Variable: MARK

Sum of

\begin{tabular}{llllll}
\hline Source & DF & Squares & Mean Square & F-value & Pr > F
\end{tabular}

$\begin{array}{llllll}\text { Model } & 1 & 4761.94571 & 4761.94571 & 14.74 & 0.0002\end{array}$

$\begin{array}{llll}\text { Error } & 138 & 44588.94000 & 323.10826\end{array}$

Corrected $139 \quad 49350.88571$

Total

\begin{tabular}{llllll}
\hline Source & DF & Type III SS & Mean Square & F-value & Pr > F \\
COMP- Lab & 1 & 4761.945714 & 4761.945714 & 14.74 & 0.0002 \\
\hline
\end{tabular}


Interpretation: From the result displayed above, the $\operatorname{Pr}>\mathrm{F}$ is less than $\alpha=0.05$ (that is $0.0002<0.05$ ). This means that we do not have enough evidence to accept the null hypothesis that Students from schools with computer laboratory and student from schools without computer laboratory have the same level of computer knowledge. In other words we are confirming that students from schools with computer laboratory will have more knowledge in computer than those students from schools without computer laboratory. This may be due to fact that students from schools with computer laboratory will have the chance to undertake practical lessons that will go a long way to enhance their understanding.

\section{CONCLUSION}

This study statistically assesses the knowledge of computer among Senior High School students in the Upper East Region of Ghana.

The results of the research indicate that the general performance of students in Senior High Schools of the Upper East Region in computer is very poor. The average mark score (in the test included in the questionnaire) of the 140 sampled students from 7 districts was 30.67 which is equivalent to $\mathrm{F}_{9}$ (Failure). And $77 \%$ of 140 sampled students failed with only $23 \%$ pass. This means that an average student in Senior High School of the Upper East Region can not pass in computer assuming it was a gradable subject.

The research further revealed that gender has no influence on the level of computer knowledge of a student. This means the level of computer knowledge of males and females is not significantly different. Meanwhile the district in which a student is attending school and the availability of a computer laboratory to students had an influence on the level of computer knowledge of the students at $\alpha=0.05$ level of significance. The difference in performance of students across districts may due to the disparity of infrastructure and development in the various districts. It was clear, that students from schools with computer laboratory performed better than those from schools without computer laboratory. This was not surprising as the students from schools with computer laboratory will have practical lessons that will go a long way to increase their understanding as the saying goes "practice makes perfect".

\section{REFERENCES}

1. Clark, R., 1983. Reconsidering research on learning with media. Rev. Educ. Res., 53: 445- 459.
2. Kozma, R., 1994. Will media influence learning? Reframing the debate. Educ. Tech. Res. Dev., 42: 7-19.

3. Oppenheimer, T., 1997. The computer delusion. Atlant. Monthly, pp: 45-62.

4. Postman, N., 1995. The end of education: Redefining the Value of School. Alfred A. Knoph Random House, Inc., 400 Hahn Road, Westminster, MD 21157 (\$22), New York, pp: 220.

http://eric.ed.gov/ERICWebPortal/custom/portlets/ recordDetails/detailmini.jsp?_nfpb=true\&_\&ERIC ExtSearch_SearchValue_0=ED392097\&ERICExtS earch_SearchType_0=no\&accno=ED392097

5. Tyack, D. and L. Cuban, 1995. Tinkering Towards Utopia. A Century of Public School Reform. Harvard University Press, Cambridge, Massachusetts, pp: 121-126

6. Vikas Gupta, 2008. Secret Guide to Computers. EPP Books Publisher, ISBN: 998807588x.

7. National ICT Policy and Plan Development Committee report, 2002. http://www.ict.gov.gh/html/press\%20conference_la unch.htm

8. Mooij, T. and Ed. Smeets, 2001. Modelling and supporting ICT implementation in secondary schools. 36: 265-281.

9. Nachmias, R., D. Mioduser and A. Shemla, 2000. Internet usage by students in an Israeli high school. J. Educ. Comput. Res., 22: 55-73.

10. Sutherland-Smith, W., I. Snyder and L. Angus, 2003. The digital divide: Differences in computer use between home and school in low socioeconomic households. L1-Educ. Stud. Language Literat., 3: 31-45.

11. Snyder, I., L. Angus and W. Sutherland, 2002. Building equitable literature futures: Home and School computer-mediated literacy practices and disadvantage. Cambridge J. Educ., 32: 368-383.

12. Education Testing Services, 2001. Digital transformation: A framework for ICT literacy. http://www.ets.org/research/ictliteracy/ictreport.pdf

13. Mucherah, W.H, 2003. The influence of technology on the classroom climate of social studies classrooms: A multidimensional approach. Learn. Environ. Res., 6: 37-57.

14. Hakkarainen, K., E. Ryymin and T. Palonen, 2008. Networking relations of using ICT within a teacher community. Comput. Educ. J., 51: 1264-1282. 